Volume 10 Nomor 1, November 2018, p.038-043

Faculty of Law, Universitas Kristen Maranatha

ISSN: 2085-9945 I e-ISSN: 2579-3520

Nationally Accredited Journal by SINTA

\title{
Perlindungan Hukum bagi Debitur Akibat Cessie Jaminan yang Dilakukan oleh BPR Tanpa Ijin Debitur Sebelum Terjadinya Likuidasi (Studi Pada BPR Yang Telah Dilikuidasi)
}

\author{
Hassanain Haykal
}

Faculty of Law, Maranatha Christian University

hassanain.haykal@gmail.com

Submitted: 2018-09-29; Reviewed: 2018-10-03; Accepted: 2018-11-22

\begin{abstract}
Bank Perkreditan Rakyat (BPR/Rural Bank) in its operational activities functions as intermediary institution. One of its operational activities is to channel credits to people, where to assure of fully debt repayment, BPR requires collateral or asset from its debtors. In spite of this, BPR as a creditor is not liquidation free that somehow it experiences the condition. Legal issue occurs when BPR approved and released cessie loan misinforming debtor before liquidation occurred. However, it is important to emphasize that cessie loan does not remove debtor obligations towards the credits/loans; cessie only diverts debtor's right of loan to another party. Debtor in the effort to retrieve collateral/asset is possible to sign a new agreement with a new creditor in a way to fully repay the loan. In addition to this, debtor is allowed to propose repayment to the original loan before cessie was applied.
\end{abstract}

Keywords: Cessie; Legal Protection; Liquidation.

\section{PENDAHULUAN}

Perbankan sebagai financial intermediary institution memegang peranan penting dalam proses pembangunan ekonomi nasional. Hal ini dapat dilihat dari berbagai kegiatan usaha utama bank, seperti menarik dana langsung dari masyarakat dalam bentuk simpanan dan menyalurkannya kembali kepada masyarakat dalam bentuk kredit dan/atau bentuk-bentuk lainnya. Pada konteks tersebut, sudah menjadi kewajiban bank untuk menerapkan prinsip kehati-hatian dalam operasionalnya, selain itu perbankan juga harus menjaga kesehatan bank agar tetap terus terjaga demi kepentingan masyarakat pada umumnya dan khususnya bagi para nasabah. 
Berdasarkan Undang-Undang Nomor 10 Tahun 1998 tentang Perubahan Atas Undang-Undang Nomor 7 Tahun 1992 tentang Perbankan, dijelaskan bahwa terdapat 2 (dua) jenis bank di Indonesia yaitu Bank Umum dan Bank Perkreditan Rakyat (BPR). Perbedaan sederhana dari kedua jenis bank tersebut terletak pada kegiatan usaha dimana BPR memiliki ruang lingkup yang lebih sempit seperti:

1. Menghimpun dana dari masyarakat dalam bentuk simpanan berupa deposito berjangka, tabungan, dan/atau bentuk lainnya yang dipersamakan dengan itu;

2. Memberikan kredit;

3. Menyediakan pembiayaan dan penempatan dana berdasarkan Prinsip Syariah, sesuai dengan ketentuan yang ditetapkan oleh Bank Indonesia;

4. Menempatkan dananya dalam bentuk Sertifikat Bank Indonesia (SBI), deposito berjangka, sertifikat deposito, dan/atau tabungan pada bank lain. Berdasarkan ruang lingkup kegiatan tersebut diharapkan BPR dapat berperan meningkatkan perekonomian masyarakat diberbagai daerah khususnya pada pemberian kredit usaha kepada masyarakat.

Pada kegiatan operasionalnya, BPR wajib memelihara tingkat kesehatan bank sesuai dengan ketentuan kecukupan modal, kualitas aset, kualitas manajemen, likuiditas, rentabilitas, solvabilitas, dan aspek lain yang berhubungan dengan usaha bank, dan wajib melakukan kegiatan usaha sesuai dengan prinsip kehati-hatian. Selanjutnya untuk kepentingan nasabah, BPR wajib menyediakan berbagai informasi mengenai kemungkinan timbulnya risiko-risiko kerugian sehubungan dengan transaksi nasabah yang dilakukan melalui BPR.

Persoalan terjadi ketika tidak semua BPR dapat terhindar dari berbagai risiko minimnya kecukupan modal, kualitas aset, kualitas manajemen, likuiditas, rentabilitas, solvabilitas, dan aspek lain yang berhubungan dengan usaha bank. Pada sisi ini, BPR tersebut berpotensi untuk dilikiuidasi yang tentunya dapat menimbulkan dampak hukum bagi debitur khususnya terkait jaminan yang terdapat di BPR. Kelebihan BPR terkait fleksibilitas persyaratan nyatanya telah berimplikasi pada berbagai persoalan hukum. Sebagai contoh ketika pihak BPR yang menyalurkan fasilitas kredit kepada nasabah, sebelum dilikuidasi telah melakukan cessie terhadap jaminan debitur kepada pihak ke tiga tanpa sepengetahuan debitur. Persoalan hukum ini tentunya berdampak pada peralihan jaminan kepada pihak ke tiga. Hal ini berimplikasi pada sulitnya debitur untuk melakukan pembayaran kredit macet masa lalu guna mendapatkan jaminannya kembali dimana kreditur yaitu BPR kini telah dilikuidasi. Adapun pengalihan ini baru diketahui debitur pada saat BPR telah dilikuidasi, hal ini memperlihatkan bahwa pengalihan jaminan debitur oleh BPR kepada kreditur baru tanpa sepengetahuan debitur. Berdasarkan permasalahan tersebut bagaimana upaya 
hukum yang dapat dilakukan debitur terhadap jaminan sebagai akibat terjadinya likiudasi BPR menjadi fokus dari penelitian ini.

\section{PEMBAHASAN}

Pada dasarnya pengalihan hutang disertai jaminan debitur oleh BPR melalui cessie dapat dilakukan kreditur dengan calon kreditur baru melalui mekanisme cessie. Subekti ${ }^{1}$ menjelaskan cessie sebagai "suatu cara pemindahan piutang atas nama, di mana piutang itu dijual oleh kreditur lama kepada orang yang nantinya menjadi kreditur baru, namun hubungan hukum utang piutang tersebut tidak hapus sedetikpun, tetapi dalam keseluruhannya dipindahkan kepada kreditur baru". Adapun menurut Soeharnoko dan Endah menjelaskan bahwa cessie adalah cara pengalihan dan atau penyerahan piutang atas nama sebagaimana yang dimaksud di dalam Pasal 613 Kitab Undang-Undang Hukum Perdata (KUHPerdata). ${ }^{2}$

Pasal 613 KUH Perdata menyebutkan bahwa "Penyerahan akan piutang-piutang atas nama dan kebendaan tidak bertubuh lainnya, dilakukan dengan jalan membuat sebuah akta otentik atau di bawah tangan, dengan mana hak-hak atas kebendaan itu dilimpahkan kepada orang lain". Penyerahan yang demikian bagi si berhutang (debitur) tidak ada akibatnya, melainkan setelah penyerahan itu diberitahukan kepadanya atau secara tertulis disetujui dan diakuinya. Penyerahan tiap-tiap piutang karena surat bawa dilakukan dengan penyerahan surat itu, penyerahan tiap-tiap piutang karena surat ditunjuk dilakukan dengan penyerahan surat disertai dengan endosemen. Unsur-unsur yang dapat disimpulkan berdasarkan Pasal 613 KUHPerdata tersebut dalam suatu tindakan cessie, yakni:

1. Dibuatkan akta otentik atau akta di bawah tangan.

2. Hak-hak yang melekat pada piutang atas nama dialihkan/berpindah kepada pihak penerima pengalihan.

3. Cessie hanya berakibat hukum kepada debitur jika telah diberitahukan kepadanya atau secara tertulis disetujui dan diakuinya.

Pada pelaksanaan cessie, pihak yang mengalihkan atau menyerahkan disebut Cedent, sedangkan pihak yang menerima pengalihan atau penyerahan disebut Cessionaris, lalu debitur dari tagihan yang dialihkan atau diserahkan disebut Cessus. ${ }^{3}$ Penyerahan utang piutang atas nama dan kebendaan tak bertubuh lainnya, dilakukan dengan jalan sebuah akta otentik atau di bawah tangan, dengan mana hak-hak atas kebendaan itu dilimpahkan kepada orang lain. Oleh karena itu, cessie harus dibuat

\footnotetext{
${ }^{1}$ Subekti, Hukum Perjanjian, Jakarta: Intermasa, 1998, hlm 71,

${ }^{2}$ Soeharnoko dan Endah Hartati, Doktrin Subrogasi, Novasi dan Cessie, Jakarta: Kencana, 2008, hlm 101.

${ }^{3}$ Herlien Budiono, Ajaran Umum Hukum Perjanjian dan Penerapannya di Bidang Kenotariatan Bandung: Citra Aditya, 2010, hlm 185.
} 
secara jelas, tegas dan tertulis. Dengan adanya penyerahan piutang secara cessie, maka pihak ketiga menjadi kreditur baru yang menggantikan kreditur yang lama, yang diikuti pula dengan beralihnya seluruh hak dan kewajiban kreditur lama terhadap debitur kepada pihak ketiga selaku kreditur baru. Hal ini dikarenakan pengalihan piutang secara cessie tidak mengakibatkan berakhirnya perikatan yang telah ada yang dibuat antara kreditur dengan debitur.

Hubungan hukum antara debitur dan kreditur berdasarkan perjanjian kredit yang telah ada sebelumnya tidak menjadi putus, sehingga tidak terjadi hubungan hukum yang baru yang menggantikan hubungan hukum yang lama. Perikatan yang lama tetap ada dan berlaku, serta mengikat debitur maupun kreditur yang menerima pengalihan piutang yang dimaksud. Dengan demikian, yang terjadi adalah pengalihan seluruh hak dan kewajiban kreditur berdasarkan perjanjian kredit yang ada kepada pihak ketiga yang selanjutnya menjadi kreditur baru. ${ }^{4}$ Dengan adanya cessie, akibat hukum yang terpenting adalah sebagai berikut: ${ }^{5}$

1. Piutang beralih dari cedent ke cessionaris.

2. Setelah terjadinya cessie, kedudukan cessionaris menggantikan kedudukan cedent, yang berarti segala hak yang dimiliki oleh cedent terhadap cessus dapat digunakan oleh cessionaris sepenuhnya.

Persoalanya ketika BPR melakukan cessie dengan tidak memberikan informasi kepada debitur, di satu sisi tentunya ini merugikan nasabah. Selanjutnya, pada Pasal 613 ayat 2 KUH Perdata tercantum ketentuan tentang adanya pemberitahuan kepada cessus, maka cessionaris mendapat kuasa dari cedent. Dalam akta tercantum ketentuan berikut: Pihak pertama dengan ini memberi kuasa kepada pihak kedua:

1. Memberitahukan kepada siapapun juga mengenai cessie ini termasuk memberitahukan dengan surat juru sita kepada siapapun juga yang berutang kepada pihak pertama;

2. Atas nama pihak pertama, pihak kedua berhak melakukan segala sesuatu yang diperlukan atau diharuskan agar piutang tagihan pihak pertama dapat dibalik nama ke atas nama pihak kedua dan diterima oleh pihak kedua.

Dari contoh akta cessie di atas, terlihat usaha kreditur untuk lebih memberi rasa aman atas dana yang dipinjamkan kepada debitur. Dengan cessie maka ada hubungan antara kreditur dengan debiturnya. Hubungan ini tercipta karena ada kewajiban cessionaris untuk memberitahukan kepada cessus akan adanya cessie tersebut (seperti yang syaratkan oleh Pasal 613 ayat 2 KUH Perdata), sehingga akan mengikat cessus

${ }^{4}$ Rachmad Setiawan dan J. Satrio, Penjelasan Hukum tentang Cessie. Jakarta: Gramedia, 2010, hlm. 47.

${ }^{5}$ Ibid, hlm 56. 
bila telah ada pemberitahuan atau secara tertulis telah disetujui dan diakui. Sedangkan hubungan ini ada karena pihak kreditur menyerahkan (cedent) hak tagihnya kepada kreditur baru. Bila para pihak akan membatalkan penyerahan hak tagihan tersebut maka harus dilakukan dengan membuat akta cessie lagi yang disebut retro cessie. Karena itu pemberitahuan atau persetujuan dari cessus sangat penting bagi cessionaris, karena bisa saja cessus membayar kepada cedent, karena tidak tahu bahwa telah ada perubahan kreditur. Dalam pelaksanaan hal demikian maka harus ada asas itikad baik. Artinya bila cessus diduga benar tidak tahu telah adanya cessie walau dari pihak luar (juga tanpa ada pemberitahuan dari cessionaris), dan cessus membayar kepada krediturnya, maka ia (cessus) mendapat perlindungan hukum. Artinya ia bebas dari hutangnya.

Persoalanya yang terjadi ketika posisi debitur dalam keadaan macet, BPR tetap wajib memberitahukan kepada debitur secara tertulis terhadap aktivitas cessie dimana hal ini tertera dalam klausula perjanjian kredit. Debitur walaupun dalam keadaan macet tentunya harus diberitahukuan oleh BPR terlepas apakah cessie tersebut dibuatkan akta otentik atau akta di bawah tangan. Dikarenakan BPR telah dilikiudasi, maka upaya hukum yang dapat dilakukan oleh debitur yaitu dengan melakukan negosiasi ulang terkait perjanjian kredit dengan kreditur baru melalui perjanjian baru, terkait upaya pelunasan debitur. Adapun pelunasan tersebut sesuai dengan jumlah pada saat BPR dan Kreditur belum melakukan cessie. Cessie terhadap jumlah tunggakan yang terus meningkat tidak berlaku karena tidak adanya pemberitahuan kepada debitur terhadap peralihan jaminan utang piutang.

Perlu disadari bahwa debitur pada dasarnya telah cidera janji, di mana debitur tidak melakukan pembayaran kepada kreditur lama sebelumnya. Pada sisi ini apabila debitur cidera janji maka yang dapat dilakukan oleh kreditur baru dapat menjual barang jaminan di muka umum dengan syarat-syarat yang lazim berlaku untuk mengambil pelunasan sejumlah piutangnya beserta bunga dan biaya dari pendapatan penjualan tersebut (Pasal 1155 ayat (1) jo. Pasal 1156 KUHPerdata). Pada hakikatnya cessie hanya merupakan salah satu model levering (pengalihan hak), di samping modelmodel peralihan hak lainnya.

\section{KESIMPULAN}

Seara prinsip pada mekanisme cessie, pihak kreditur baru (cessionaris) harus memberitahukan adanya pengalihan hak tagih kepada debitur, sehingga apabila terjadi pembayaran yang dilakukan oleh debitur kepada debitur lama karena tidak adanya pemberitahuan kepada debitur, maka pembayaran sebagaimana dimaksud dianggap sah dan berlaku. Adapun sisa kredit yang harus dilunasi oleh debitur macet, harus didasarkan pada perhitungan sebelum dilakukannya cessie. Di samping itu, cessie tidak menghapus kewajiban debitur terhadap utang piutang, cessie hanya pengalihan 
hak BPR kepada kreditor baru. Debitur dalam upayanya mendapatkan jaminannya kembali dapat melakukan upaya penyelesaian melalui perjanjian baru terkait upaya pelunasan tagihan. Adapun debitur dapat mengajukan pelunasan dengan jumlah utang pada saat belum dilakukannya cessie. Adapun hal ini dapat dilakukan ketika kreditur baru masih memiliki jaminan dari kreditur lama.

\section{DAFTAR PUSTAKA}

\section{Buku}

Herlien Budiono. Ajaran Umum Hukum Perjanjian dan Penerapannya di Bidang Kenotariatan. Bandung: Citra Aditya, 2010.

Rachmad Setiawan dan J. Satrio, Penjelasan Hukum tentang Cessie, Jakarta: Gramedia, 2010.

Soeharnoko dan Endah Hartati, Doktrin Subrogasi, Novasi dan Cessie, Jakarta: Kencana, 2008.

Subekti, Hukum Perjanjian, Jakarta: Intermasa, 1998.

\section{Jurnal}

Mohammad Wisno Hamin, "Perlindungan Hukum Bagi Nasabah (Debitur) Bank Sebagai Konsumen Pengguna Jasa Bank Terhadap Risiko Dalam Perjanjian Kredit Bank", Jurnal Lex Crimen, Vol. VI, No. 1. 